\title{
Influence of Selected Biomarkers on Stress and Alexithymia in Patients Under Hemodialysis Treatment
}

\author{
Esra Tayaz* and Ayşegül Koç* \\ *Ankara Yildirim Beyazit University, Gazze Province Nu:2 Medical Sciences Faculty, Etlik, Ankara, Turkey
}

\begin{abstract}
Background Hemodialysis treatment and the high stress brought about by the treatment are the circumstances which set the background for alexithymia. Alexithymic feelings basically emerge as restriction in the world of emotion and thought, and the inability to recognize physiological changes. Biomarkers that are indicators of physical change are influential in the stress lives of individuals. This research was carried out to discover the relationships between, and to determine the influence of urea, creatinine, sodium, potassium, hemoglobin, hematocrit, albumin, calcium, phosphorus and C-reactive protein biomarkers on stress and alexithymia in individuals, who are diagnosed with chronic renal failure and receive hemodialysis treatment.
\end{abstract}

Methods The research environment was formed of patients who underwent hemodialysis treatment in a hospital in Turkey. The subject group was comprised of 72 individuals. Demographic data form, biomarker list form, Hemodialysis Stressor Scale and Toronto Alexithymia Scale were used in the research.

Results It was found that the levels of perceived stress of individuals who participated in the research were high at all dimensions, and 59.7\% were alexithymic. The means of the total scale scores of all patients were calculated as $87.81 \pm 13.59$ for Hemodialysis Stressor Scale and $62.46 \pm 9.84$ for Toronto Alexithymia Scale. The relationship between the Toronto Alexithymia Scale and Hemodialysis Stressor Scale and selected biomarkers were determined $(P<0.05)$.

Conclusion It was concluded that stress and alexithymic feelings were high in patients who received hemodialysis treatment, and that there is a relationship between C-reactive protein, creatinine, sodium, hemoglobin, hematocrit, potassium from the biomarkers and the scales and scale sub-dimensions. It is necessary to increase the awareness of nurses on the importance of the skills to communicate with individuals who have to cope with stress, manage emotions, and have high stress and emotional deprivation.

Key words alexithymia; biomarkers; chronic renal failure; hemodialysis; stress
While chronic renal failure (CRF) causes many physical problems in patients, sick individuals are also psychologically and socially influenced by hemodialysis treatment and the feeling of being dependent on a mechanical instrument brought about by the treatment. CRF patients under hemodialysis treatment constitute a specific group due to changes not only in their health but also in other social environments. ${ }^{1,2}$ Hemodialysis treatment gives rise to basic fluid electrolyte imbalances. ${ }^{3}$ The stress levels in such patients rise due to physical and psychological problems that emerge during the uremic period, sudden changes in biomarkers, medication treatment, diet treatment and hemodialysis treatment. ${ }^{2,}{ }^{4}$ And when the increased stress becomes continuous, it sets the ground for alexithymia in direct proportion to the disease. ${ }^{5}$

Alexithymia is defined as restriction in imagination and lack of ability to fantasize, inadequacy in distinguishing between emotions, thoughts and physiological reactions, and problems in recognizing and expressing emotions. ${ }^{6}$ Alexithymic behavior patterns observed in patients have been defined as: nervousness, short temperedness, touchiness, introversion, loss of interest and desire, loss of hope for the future, distress, anxiety and emotional deprivation as a result of these. ${ }^{5,7}$ Feelings such as fear, anger, and sorrow in alexithymic individuals create a loss in persuasive properties and may cause individuals to mask their emotions in some way. ${ }^{8}$ It has been observed that alexithymia studies in the literature are primarily concentrated on psychiatric diseases. ${ }^{9}$ As a result of our research, we found out that alexithymia can be observed in individuals who have chronic diseases, even if they have not been identified in conducted research. ${ }^{10,11}$ Senturk et al. (2000) reported that CRF patients who received hemodialysis treatment had an intermediate level of depression, while more

Corresponding: Esra Tayaz

esratayaz@gmail.com

Received 2019 August 22

Accepted 2019 October 30

Online published 2019 November 22

Abbreviations: $\mathrm{CRF}$, chronic renal failure; CRP, c-reactive protein; HSS, hemodialysis stressor scale; HSS-1, physical stressors; HSS-2, psychosocial stressors; TAS-20, Toronto alexithymia scale; TAS-1, difficulty identifying feelings; TAS-2, difficulty expressing emotions; TAS-3, outward-thinking 
than half of them were alexithymic. ${ }^{5}$ In their research, Pop-Jordanova and Polenakovic (2014) determined that half of the patients who received hemodialysis treatment were alexithymic, irrespective of sex, and the comparison they made with healthy individuals and cancer patients emphasized that alexithymia was higher in patients who received hemodialysis treatment as compared to the other groups. ${ }^{12}$ In their research, Kojima et al. (2007) concluded that hemodialysis patients were prone to depression and were alexithymic. ${ }^{13}$

Nursing care includes the planning and implementation of appropriate attempts aimed at relieving stress in the patient, the quality of life from a biological, psychosocial and socio-cultural perspective, and realizing the ability of the individual to cope with stress factors or the problems that develop as a result of the stressors. ${ }^{14}$ It is not appropriate to handle symptom management or the psychosocial dimension of CRF solely through a nursing approach. ${ }^{15}$ Therefore, a nurse has to adopt a holistic approach while performing care activities during CRF and hemodialysis treatment.

In this research, which was not initially designed as experimental, we planned to obtain evidence that physical findings obtained from tangible data may be related to alexithymia as a psychological phenomenon. As the main idea underlying the research design, we thought that biomarkers that changed biochemically in the blood and serum in chronic kidney failure could be recorded as tangible data and the physical changes that occurred in the body could be related to alexithymia as stress on a structured scale. Thus, the alexithymia and stress table of hemodialysis patients could be discovered in proportion to the pre-treatment and post-treatment changes in their biomarkers. We believe that our study could assist nurses who work as care providers for CRF patients receiving hemodialysis treatment by providing holistic care through evaluating the relationship of the biomarkers with the stress levels and alexithymia of the patients, and developing a guide aimed toward helping such patients. Accordingly, the research was conducted in order to evaluate the relationship between the selected biomarkers of patients who receive hemodialysis treatment with stress and alexithymia.

\section{MATERIALS AND METHODS}

The prospective cross-sectional demographic data of our study was designed to assess the relationship between biomarkers, hemodialysis stressors and alexithymia. Our study was conducted in a hospital hemodialysis unit in Turkey, and data was collected. The sample was comprised of 72 hemodialysis patients.
The inclusion criteria were:

- taking hemodialysis treatment for six months or more due to CRF diagnosis

- being eighteen years of age or older

- being literate in Turkish, reading the informed consent form and agreeing to participate in the work; The exclusion criteria were:

- having a psychiatric diagnosis, tumor and/or metastasis

- taking hemodialysis treatment without a diagnosis of CRF

- undergoing hemodialysis treatment with a diagnosis of CRF for less than 6 months.

Patients' demographic characteristics: the data collection form as prepared by the researcher in relation to the hemodialysis treatment to determine the patients' demographic data was used in this research. This form included 11 questions, including patients' sociodemographic data, how many medications they took, hemodialysis acquisition time, age, gender, additional chronic disease status, education status, marital status, income level, occupation and working status.

On the biomarker list, the values of the following were noted for collection: urea, creatinine, hemogram, hematocrit, albumin, sodium, potassium, $\mathrm{C}$ reactive protein (CRP).

Hemodialysis stressor scale (HSS): the Hemodialysis Stressor Scale was used to determine stress. The scale was developed by Baldree et al. and was adapted for Turkish patients by Kara. ${ }^{14}$ The HSS is a five-point Likert-type scale and is coded as "always" 5 , "often" 4, "sometimes" 3, "rarely" 2 and "never" 1. HSS has been identified in hemodialysis patients as physical (HSS-1) and psychosocial (HSS-2). ${ }^{16}$ The physical hemodialysis stressor score is 6-30 and the psychosocial hemodialysis stressor score is $23-115$ points. The total score of HSS varies between $29-145$ points. The total HSS score ranges from 29-145 and an increased score on the scale indicates that the perceived stress level is higher. ${ }^{16}$

The Toronto Alexithymia Scale (TAS-20): the Toronto Alexithymia Scale was used to measure alexithymia. The self-reporting scale consists of 20 items evaluating alexithymia, with a score of $1-5$, likert-type and three subscales: "difficulty identifying feelings" (TAS-1), "difficulty expressing emotions" (TAS-2) and "outward-thinking" (TAS-3). Individuals are asked to mark the most appropriate score for each item from "never", "rarely", "sometimes", "often" and "always". This scale was developed by Bagby et al. (1994) and Turkish adaptation was done by Gulec et al. (2009). Items $4,5,10,18$ and 19 on the scale are scored in 
Table 1. Percentage distributions according to alexithymia levels of hemodialysis patients $(n=72)$

\begin{tabular}{lcc}
\hline & Sample $(n)$ & Percent $(\%)$ \\
\hline No alexithymia (51 points and below) & 10 & 13.9 \\
Possible alexithymia (52-60 points) & 19 & 26.4 \\
Alexithymia (61 points and above) & 43 & 59.7 \\
\hline
\end{tabular}

reverse ${ }^{17}$; the cut-off value of TAS-20 is 51 or less with $52-60$ indicating possible alexithymia and a score of $>$ 61 indicating alexithymia. ${ }^{18}$

\section{Data collection and procedure}

This research was carried out between 03.08.2016 and 04.04.2017. The single measurement biomarker values of the participants in the study's planning stage were examined. The biomarker values were measured immediately before taking hemodialysis treatment and evaluations were done as follows: information was given verbally prior to application, then confirmed by filling in informed consent forms, and finally approved on the basis of volunteerism. The questionnaires were performed as face-to-face interviews by the researcher and coded with patients' initials and protocol numbers in order to prevent repetition of information.

\section{Analysis}

The distribution of continuous variables such as age, albumin, and CRP in the study were examined by the Shapiro-Wilk test and normality graphs. All continuous measurements were expressed as mean \pm standard deviation (mean $\pm \mathrm{s}$ ), the number of drugs used daily was median (min-max), and categorical variables were expressed as number (n) and percentage (\%). The consistency of responses to HSS and TAS-20 was assessed with Cronbach's $\alpha$. Subgroups of HSS, TAS-20, and scales were tested by the Mann-Whitney $U$ test and independent sample tests ( $t$ test and $\chi^{2}$ test) according to gender and additional chronic illness status, the Kruskal-Wallis test, and one-way ANOVA according to marital status and hemodialysis time. Relationships between scale scores, biomarkers, and the number of drugs used daily were examined by Pearson or Spearman Correlation analyses depending on the distribution of variables. Statistical significance level was $P<$ 0.05 . Cronbach's $\alpha$ value for HSS in our study was 0.789 and for TAS-20, 0.737. Accordingly, the consistency of responses to the scale was acceptable $(0.70<\alpha<0.80)$.

\section{Limitations}

Only a single center was studied, the number of sessions was not examined as a variable, and only a single measurement was used before hemodialysis. These conditions were determined as limitations of the study.

\section{RESULTS}

The following findings were obtained in the data obtained from our study. When the alexithymia levels of subjects participating in the study were examined, it was found that $59.7 \%(n=43)$ were alexithymic (Table $1)$.

Among the individuals included in our study, $55.6 \%(n=40)$ were men, $66.7 \%(n=48)$ were married, and $63.9 \%(n=46)$ had additional chronic diseases. Hemodialysis durations were $30.6 \%(n=22)$ for six months to two years, $27.7 \%(n=20)$ for $2-5$ years, $15.3 \%(n=10)$ for $5-8$ years, $8.3 \%(n=6)$ for $8-10$ years, and $18.1 \%(n=13)$ for $>10$ years (Table 2$)$. The relationship between the subscales of demographic data, HSS, HSS subscales, TAS-20, and TAS-20 subscales are shown in Table 2. Additional chronic disease and the HSS-1 subscale were statistically significant.

The biomarkers of urea, creatinine, hemoglobin, hematocrit, albumin, sodium, potassium, calcium, phosphorus, and $\mathrm{C}$-reactive protein (CRP) values of the subjects who participate in the study were evaluated. The median number of medications used by the patients on a daily basis was three (min-max: 1-20). Normally deviating values were determined and the relationship between the HSS, HSS subscales, TAS-20, and TAS-20 subscale scores was assessed. A positive correlation was found between the TAS-20 point average and the HSS-1, between the HSS score average and TAS-1, between CRP and HSS, HSS-2 and the number of drugs used daily and HSS-1 in the direction of the obtained results. There was a negative correlation between creatinine and HSS-1, TAS-20, TAS-2, TAS-3, between hemoglobin and TAS-1, between hematocrit and TAS-1, between sodium and HSS-1, between potassium and TAS-3 (Table 3).

\section{DISCUSSION}

Emotional disorders, time, diet and functional restrictions, self-change and fear of death are quite high for individuals who are under chronic hemodialysis treatment in addition to the exhaustion originating from 
Table 2. Demographic data rates of individuals who received hemodialysis treatment, evaluation of demographic data with HSS, HSS subscales, TAS-20, TAS-20 subscales

\begin{tabular}{|c|c|c|c|c|c|c|c|c|c|}
\hline $\begin{array}{l}\text { Charateris- } \\
\text { tics }\end{array}$ & Categories & $n(\%)$ & $\begin{array}{c}\text { HSS } \\
\overline{\mathrm{x}} \pm \mathrm{SD}\end{array}$ & $\begin{array}{l}\mathrm{HSS}-1 \\
\overline{\mathrm{x}} \pm \mathrm{SD}\end{array}$ & $\begin{array}{l}\text { HSS-2 } \\
\overline{\mathrm{x}} \pm \text { SD }\end{array}$ & $\begin{array}{l}\text { TAS-20 } \\
\overline{\mathrm{x}} \pm \mathrm{SD}\end{array}$ & $\begin{array}{l}\text { TAS-1 } \\
\bar{x} \pm \text { SD }\end{array}$ & $\begin{array}{l}\text { TAS-2 } \\
\bar{x} \pm \mathrm{SD}\end{array}$ & $\begin{array}{l}\text { TAS-3 } \\
\overline{\mathrm{x}} \pm \mathrm{SD}\end{array}$ \\
\hline Gender & $\begin{array}{l}\text { Female } \\
\text { Male } \\
P\end{array}$ & $\begin{array}{l}32(44.4) \\
40(55.6)\end{array}$ & $\begin{array}{c}88.94 \pm 10.86 \\
86.90 \pm 15.52 \\
0.563\end{array}$ & $\begin{array}{c}19.03 \pm 3.93 \\
17.47 \pm 4.21 \\
0.113\end{array}$ & $\begin{array}{c}69.91 \pm 9.99 \\
69.42 \pm 13.50 \\
0.867\end{array}$ & $\begin{array}{c}62.19 \pm 9.49 \\
62.67 \pm 10.22 \\
0.836\end{array}$ & $\begin{array}{c}20.34 \pm 3.93 \\
20.35 \pm 4.71 \\
0.636\end{array}$ & $\begin{array}{c}14.81 \pm 3.30 \\
14.62 \pm 4.05 \\
0.833\end{array}$ & $\begin{array}{c}27.03 \pm 4.95 \\
27.70 \pm 4.55 \\
0.586\end{array}$ \\
\hline $\begin{array}{l}\text { Marital } \\
\text { status }\end{array}$ & $\begin{array}{l}\text { Married } \\
\text { Single } \\
\text { Divorced } \\
P\end{array}$ & $\begin{array}{l}48(66.7) \\
14(19.4) \\
10(13.9)\end{array}$ & $\begin{aligned} & 88.21 \pm 14.81 \\
& 87.93 \pm 11.51 \\
& 85.70 \pm 10.71 \\
& 0.661\end{aligned}$ & $\begin{array}{c}18.40 \pm 4.17 \\
18.29 \pm 4.08 \\
16.90 \pm 4.22 \\
0.694\end{array}$ & $\begin{array}{c}69.81 \pm 13.21 \\
69.64 \pm 9.52 \\
68.80 \pm 9.51 \\
0.972\end{array}$ & $\begin{array}{c}60.73 \pm 9.08 \\
64.29 \pm 11.34 \\
68.20 \pm 9.47 \\
0.066\end{array}$ & $\begin{array}{c}20.00 \pm 4.64 \\
20.64 \pm 3.52 \\
21.60 \pm 4.09 \\
0.247\end{array}$ & $\begin{array}{c}14.19 \pm 3.56 \\
15.07 \pm 4.06 \\
16.70 \pm 3.53 \\
0.138\end{array}$ & $\begin{aligned} & 26.54 \pm 4.55 \\
& 28.57 \pm 5.32 \\
& 29.90 \pm 3.60 \\
& 0.053\end{aligned}$ \\
\hline $\begin{array}{l}\text { Chronic } \\
\text { disease }\end{array}$ & $\begin{array}{l}\text { Yes } \\
\text { No } \\
P\end{array}$ & $\begin{array}{l}46(63.9) \\
26(26.1)\end{array}$ & $\begin{array}{c}88.67 \pm 11.32 \\
86.27 \pm 17.04 \\
0.837\end{array}$ & $\begin{array}{c}19.33 \pm 3.52 \\
11.12 \pm 4.39 \\
\mathbf{0 . 0 0 1}\end{array}$ & $\begin{array}{c}69.35 \pm 10.35 \\
70.15 \pm 14.66 \\
0.786\end{array}$ & $\begin{array}{c}64.15 \pm 8.78 \\
59.46 \pm 11.02 \\
0.051\end{array}$ & $\begin{array}{c}21.04 \pm 4.11 \\
19.12 \pm 4.56 \\
0.185\end{array}$ & $\begin{array}{c}14.93 \pm 3.60 \\
14.31 \pm 3.94 \\
0.495\end{array}$ & $\begin{array}{c}28.17 \pm 4.44 \\
26.04 \pm 4.94 \\
0.099\end{array}$ \\
\hline $\begin{array}{l}\text { Duration of } \\
\text { hemodialysis }\end{array}$ & $\begin{array}{l}6 \text { months- } \\
2 \text { years } \\
2-5 \text { years } \\
5-8 \text { years } \\
8-10 \text { years } \\
10 \text { years } \\
\text { and more } \\
P\end{array}$ & $\begin{array}{l}22(30.6) \\
20(27.7) \\
11(15.3) \\
6(8.3) \\
13(18.1)\end{array}$ & $\begin{array}{l}89.64 \pm 18.96 \\
88.85 \pm 10.83 \\
82.18 \pm 8.64 \\
83.50 \pm 3.94 \\
89.85 \pm 12.61\end{array}$ & $\begin{array}{c}19.05 \pm 3.24 \\
16.27 \pm 3.32 \\
15.67 \pm 4.41 \\
19.15 \pm 4.36 \\
0.162\end{array}$ & $\begin{array}{l}71.23 \pm 16.43 \\
69.80 \pm 9.79 \\
65.91 \pm 8.38 \\
67.83 \pm 6.49 \\
70.69 \pm 11.41\end{array}$ & $\begin{aligned} & 62.45 \pm 11.38 \\
& 63.50 \pm 7.82 \\
& 61.45 \pm 10.44 \\
& 65.17 \pm 9.66 \\
& 60.46 \pm 10.42 \\
& 0.864\end{aligned}$ & $\begin{array}{c}21.27 \pm 5.70 \\
20.00 \pm 3.91 \\
20.00 \pm 3.03 \\
21.67 \pm 2.34 \\
19.00 \pm 4.04 \\
0.427\end{array}$ & $\begin{array}{l}14.45 \pm 4.28 \\
15.10 \pm 3.14 \\
14.18 \pm 3.34 \\
15.50 \pm 4.23 \\
14.62 \pm 3.99\end{array}$ & $\begin{array}{l}26.73 \pm 4.94 \\
28.40 \pm 3.63 \\
27.27 \pm 5.98 \\
28.00 \pm 4.60 \\
26.85 \pm 5.10\end{array}$ \\
\hline
\end{tabular}

the disease. Many problems that exist in this patient group were found to be factors in the development of alexithymia. Both the literature and the results of our study suggest that alexithymia is observed at high levels in chronic diseases (Table 1). Pop-Jordanova and Polenakovic reported that half of the patients who received hemodialysis treatment in Macedonia $(n=$ 230) appeared alexithymic. ${ }^{12}$ In a study they conducted, Sinatra et al. (2011) found that the primary psychiatric outlook that accompanied depression was alexithymia in patients under hemodialysis treatment for 4 years and above..$^{19}$ As a result of our research, we found that the increase in the length of hemodialysis treatment is in direct proportion to the emergence of alexithymic symptoms.

It was reported that $31.5 \%$ of the subjects received hemodialysis treatment for nine months or less, $32.5 \%$ received treatment between 9 and 24 months, and 36\% were under hemodialysis treatment for more than 24 months in research conducted by Davison and Jhangri (2005), while the mean hemodialysis treatment period of hemodialysis patients was reported as $58.75 \pm 48.94$ months in a different study. ${ }^{20,}{ }^{21}$ In our research, we determined that 22 patients $(30.6 \%)$ had begun hemodialysis for 6 months-2 years, 20 patients (27.7\%) for 2-5 years, 11 patients (15.3\%) for 5-8 years, 6 patients (8.3\%) for $8-10$ years and 13 patients $(18.1 \%)$ for more than 10 years (Table 2). The exposure of hemodialysis patients to physical and psychological changes that they have to cope with increases in direct proportion to the increase in their treatment periods. This process based on a patient's experience with hemodialysis should be carefully followed up also with respect to the patient and healthcare employees.

Physiological changes such as edema and ultrafiltration during hemodialysis treatment may render the biomarkers of individuals unstable. In a study conducted by Griva et al., it was found that the hemoglobin value was low in hemodialysis treatment. ${ }^{22}$ In a systematic compilation, statistical significance was reported with respect to living quality in health and the 3 sub-dimensions that examined CRP value in hemodialysis patients. ${ }^{23}$ In a study where Kalender et al. evaluated the biomarkers with respect to receiving hemodialysis treatment for 2 or 3 sessions per week, they found that the hemoglobin, hematocrit, albumin and calcium values were higher in individuals who received hemodialysis treatment in 3 sessions per week, while urea, creatinine, potassium and phosphorus values where higher in individuals who received hemodialysis treatment in 2 sessions per week. In conclusion, they found that the treatment adequacy of individuals who received hemodialysis treatment for 3 sessions per week was higher as compared to those who received 2 sessions per week. ${ }^{24}$ When we examined studies evaluating hemodialysis patients, we observed that biomarkers have multi-dimensional influences on the health of patients. We believed that these parameters increased the hemodialysis origin stress of patients and 
Table 3. Assessment of the relationship between biomarkers, total score average of TAS-20, total mean score of HSS and the number of daily medicines used by HSS, HSS subscales, TAS-20, TAS-20 subscales

\begin{tabular}{|c|c|c|c|c|c|c|c|c|c|}
\hline Biomarkers & $\overline{\mathrm{x}} \pm \mathrm{SD}$ & & HSS & HSS-1 & HSS-2 & TAS-20 & TAS-1 & TAS-2 & TAS-3 \\
\hline TAS-20 & $62.46 \pm 9.84$ & $\begin{array}{l}r \\
P\end{array}$ & $\begin{array}{l}0.081 \\
0.500\end{array}$ & $\begin{array}{l}0.241 \\
\mathbf{0 . 0 4 2}\end{array}$ & $\begin{array}{l}0.034 \\
0.774\end{array}$ & - & - & - & - \\
\hline HSS & $87.81 \pm 13.59$ & $\begin{array}{l}r \\
P\end{array}$ & - & - & - & $\begin{array}{l}0.081 \\
0.500\end{array}$ & $\begin{array}{l}0.251 \\
0.033\end{array}$ & $\begin{array}{l}0.140 \\
0.242\end{array}$ & $\begin{array}{r}-0.162 \\
0.174\end{array}$ \\
\hline Urea & $131.47 \pm 30.45$ & $\begin{array}{l}r \\
P\end{array}$ & $\begin{array}{r}-0.003 \\
0.982\end{array}$ & $\begin{array}{c}-0.137^{*} \\
0.250\end{array}$ & $\begin{array}{c}-0.009 * \\
0.939\end{array}$ & $\begin{array}{c}-0.120 * \\
0.316\end{array}$ & $\begin{array}{l}0.021 \\
0.861\end{array}$ & $\begin{array}{c}-0.117 * \\
0.329\end{array}$ & $\begin{array}{r}-0.121 \\
0.310\end{array}$ \\
\hline Creatinine & $8.34 \pm 2.57$ & $\begin{array}{l}r \\
P\end{array}$ & $\begin{array}{r}-0.073 \\
0.542\end{array}$ & $\begin{array}{c}-0.285^{*} \\
\mathbf{0 . 0 1 5}\end{array}$ & $\begin{array}{c}-0.112^{*} \\
0.349\end{array}$ & $\begin{array}{c}-0.337^{*} \\
\mathbf{0 . 0 0 4}\end{array}$ & $\begin{array}{r}-0.203 \\
0.088\end{array}$ & $\begin{array}{c}-0.309^{*} \\
\mathbf{0 . 0 0 8}\end{array}$ & $\begin{array}{r}-0.251 \\
\mathbf{0 . 0 3 3}\end{array}$ \\
\hline Hemoglobin & $11.47 \pm 1.66$ & $\begin{array}{l}r \\
P\end{array}$ & $\begin{array}{r}-0.118 \\
0.322\end{array}$ & $\begin{array}{l}0.089^{*} \\
0.458\end{array}$ & $\begin{array}{l}0.050^{*} \\
0.675\end{array}$ & $\begin{array}{c}-0.071^{*} \\
0.556\end{array}$ & $\begin{array}{r}-0.277 \\
\mathbf{0 . 0 1 8}\end{array}$ & $\begin{array}{l}0.072 * \\
0.550\end{array}$ & $\begin{array}{r}-0.104 \\
0.386\end{array}$ \\
\hline Hematocrit & $34.00 \pm 4.99$ & $\begin{array}{l}r \\
P\end{array}$ & $\begin{array}{r}-0.108 \\
0.368\end{array}$ & $\begin{array}{l}0.060^{*} \\
0.619\end{array}$ & $\begin{array}{c}-0.031^{*} \\
0.798\end{array}$ & $\begin{array}{c}-0.065^{*} \\
0.589\end{array}$ & $\begin{array}{r}-0.281 \\
\mathbf{0 . 0 1 7}\end{array}$ & $\begin{array}{l}0.094^{*} \\
0.431\end{array}$ & $\begin{array}{r}-0.137 \\
0.252\end{array}$ \\
\hline Albumin & $3.58 \pm 0.58$ & $\begin{array}{l}r \\
P\end{array}$ & $\begin{array}{r}-0.155 \\
0.201\end{array}$ & $\begin{array}{r}-0.133 \\
0.271\end{array}$ & $\begin{array}{r}-0.139 \\
0.253\end{array}$ & $\begin{array}{r}-0.120 \\
0.324\end{array}$ & $\begin{array}{r}-0.189 \\
0.117\end{array}$ & $\begin{array}{l}0.058 \\
0.633\end{array}$ & $\begin{array}{r}-0.191 \\
0.112\end{array}$ \\
\hline Sodium & $135.56 \pm 2.99$ & $\begin{array}{l}r \\
P\end{array}$ & $\begin{array}{r}-0.076 \\
0.526\end{array}$ & $\begin{array}{r}-0.236 \\
\mathbf{0 . 0 4 6}\end{array}$ & $\begin{array}{l}0.008 \\
0.950\end{array}$ & $\begin{array}{l}0.037 \\
0.755\end{array}$ & $\begin{array}{r}-0.027 \\
0.825\end{array}$ & $\begin{array}{l}0.101 \\
0.398\end{array}$ & $\begin{array}{l}0.024 \\
0.839\end{array}$ \\
\hline Potassium & $5.23 \pm 0.71$ & $\begin{array}{l}r \\
P\end{array}$ & $\begin{array}{l}0.050 \\
0.676\end{array}$ & $\begin{array}{c}-0.016^{*} \\
0.894\end{array}$ & $\begin{array}{l}0.062 * \\
0.608\end{array}$ & $\begin{array}{c}-0.197^{*} \\
0.098\end{array}$ & $\begin{array}{l}0.025 \\
0.837\end{array}$ & $\begin{array}{c}-0.071^{*} \\
0.556\end{array}$ & $\begin{array}{r}-0.283 \\
\mathbf{0 . 0 1 6}\end{array}$ \\
\hline Calcium & $8.79 \pm 0.84$ & $\begin{array}{l}r \\
P\end{array}$ & $\begin{array}{l}0.126 \\
0.295\end{array}$ & $\begin{array}{l}0.027^{*} \\
0.821\end{array}$ & $\begin{array}{l}0.098^{*} \\
0.417\end{array}$ & $\begin{array}{l}0.036^{*} \\
0.745\end{array}$ & $\begin{array}{l}0.134 \\
0.265\end{array}$ & $\begin{array}{c}-0.032 * \\
0.788\end{array}$ & $\begin{array}{r}-0.095 \\
0.429\end{array}$ \\
\hline Phosphorus & $5.34 \pm 1.37$ & $\begin{array}{l}r \\
P\end{array}$ & $\begin{array}{l}0.130 \\
0.291\end{array}$ & $\begin{array}{c}-0.038^{*} \\
0.761\end{array}$ & $\begin{array}{l}0.162^{*} \\
0.186\end{array}$ & $\begin{array}{c}-0.048^{*} \\
0.699\end{array}$ & $\begin{array}{l}0.018 \\
0.884\end{array}$ & $\begin{array}{c}-0.033^{*} \\
0.791\end{array}$ & $\begin{array}{r}-0.093 \\
0.449\end{array}$ \\
\hline C-reactive protein & $15.15 \pm 19.64$ & $\begin{array}{l}r \\
P\end{array}$ & $\begin{array}{l}0.385 \\
0.015\end{array}$ & $\begin{array}{l}0.148 \\
0.370\end{array}$ & $\begin{array}{l}0.322 \\
\mathbf{0 . 0 4 6}\end{array}$ & $\begin{array}{r}-0.081 \\
0.623\end{array}$ & $\begin{array}{l}0.135 \\
0.412\end{array}$ & $\begin{array}{r}-0.018 \\
0.912\end{array}$ & $\begin{array}{r}-0.163 \\
0.321\end{array}$ \\
\hline $\begin{array}{l}\text { Number of } \\
\text { medications used } \\
\text { daily }\end{array}$ & $\begin{array}{c}\text { Median } 3 \\
\text { (min-max: } \\
1-20)\end{array}$ & $\begin{array}{l}r \\
P\end{array}$ & $\begin{array}{l}0.110 \\
0.358\end{array}$ & $\begin{array}{l}0.266 \\
\mathbf{0 . 0 2 4}\end{array}$ & $\begin{array}{r}-0.006 \\
0.957\end{array}$ & $\begin{array}{l}0.037 \\
0.758\end{array}$ & $\begin{array}{l}0.002 \\
0.984\end{array}$ & $\begin{array}{l}0.032 \\
0.791\end{array}$ & $\begin{array}{r}-0.009 \\
0.941\end{array}$ \\
\hline
\end{tabular}

*Pearson correlation coefficient, others spearman correlation coefficient.

set the background for alexithymic to arise.

When we evaluated the variables with HSS and HSS sub-dimensions in our study, we concluded that there was no relationship between the sex, marital status, hemodialysis period, accompanying chronic disease variables and the mean scores of the scale and scale sub-dimensions $(P>0.05)$. The relationship between the presence of accompanying chronic disease and HSS physical sub-dimension mean scores was found to be statistically significant $(t=3.394, P=0.001)$. In their study, Shahrokhi et al. (2014) reported that there was no statistically significant relationship between the type of hemodialysis dependent stressor, and sex, marital status, educational status, number of weekly hemodialysis sessions and hemodialysis period. ${ }^{25}$ Mok and Tam (2001) reported similar conclusions in their findings. ${ }^{26}$ In a similar study, Ahmad and Nazly (2015) reported that there is a negative relationship between coping with stress and seeking social support as the hemodialysis period increases. When they examined individuals receiving hemodialysis treatment as based on the sex variable in the same study, they reported that there is a positive relationship between HSS, HSS physical and psychosocial sub-dimensions and the differences between them was statistically significant. ${ }^{27}$ Most of the physical stressors include fatigue, fluid restriction, nutrition limitations, and difficulty with dressing due to arterial and venous catheterization. Meanwhile, most of the psychosocial stressors may be considered as loss of time, problems with disorientation, transportation, sleeping disorders, dependence and boredom. At the same time, we may also include changes of roles in the family with respect to children, isolation and transfer problems. It was concluded that these variables are influential on hemodialysis origin stress.

We compared the scores of the patients from the Toronto Alexithymia Scale and sub-dimensions with sex, marital status, accompanying chronic disease status 
and periods of entering hemodialysis (Table 2). We determined the TAS-20 mean scores of female patients as $62.19 \pm 9.49$, and that of the male patients as $62.67 \pm$ 10.22. We determined a similarity in TAS-20 scores as based on sex $(t=0.208, P=0.836)$. When we examined the scores of the TAS-20 sub-dimensions with respect to sex, we determined that the mean scores were similar and concluded that sex is not related to alexithymia $(P>$ $0.05)$. The TAS-20 mean scores and the mean scores of the sub-dimensions were not statistically significant as based on marital status $(P>0.05)$. Pistorio et al. (2017) found that patients who were in the process of kidney transplantation and had physical and somatic complaints exhibited a more alexithymic appearance and the difference between them was statistically significant. In the same study, they reported that there was no relationship when examined based on the sex variable. ${ }^{10}$ In a study that Pop-Jordanova et al. conducted (2014), they reported that there is a linear relationship between age and alexithymia. At the same time, they found that alexithymic appearance was relatively higher in males when evaluated based on sex. When they examined with factor analysis based on TAS-20 sub-dimensions, they found that TAS- 1 and TAS-2 age and hemodialysis entry periods were not significant, while the TAS-3 extroverted thinking sub-dimension was significant. ${ }^{12}$ As reported in a study conducted in Japan, individuals under end-stage renal failure were divided into two groups based on depression scores and their alexithymic appearances were examined. It was reported that the alexithymic appearance was higher in individuals who had high depression scores. In this study, they reported that there is a negative relationship between period of beginning hemodialysis and alexithymic appearance. ${ }^{13}$ End-stage renal failure and the physical stress created by the fluid changes during hemodialysis treatment lead to psychosomatic complaints and this condition negatively influences appearance as the treatment period increases. Furthermore, accompanying chronic diseases and other psychiatric appearances, and the inability of the individual to distinguish between feelings that are expressed as emotional obtuseness increase alexithymia. The individual who appears alexithymic experiences difficulty in managing the treatment processes, and this may at the same time cause his physical condition to get worse.

Correlation analysis was made between the scores that hemodialysis patients received from the HSS and HSS physical, psychosocial sub-dimensions and the biochemistry results and the number of daily medications used (Table 3). In one study (Harwood et al. 2009), the biomarkers of CRF patients were found to be associated directly with their stress and coping strategies and found them to be statistically significant. While hemoglobin and albumin from these parameters were statistically significant, it was reported that urea and creatinine parameters were not influential on stress. ${ }^{28}$ Accordingly, the biomarker change of individuals may make it difficult to cope with stress since it influences their fatigue levels. The pre-session biomarker data on hemodialysis patients may provide information also on psychosocial variables, in addition to the individual's potential physical condition. Nurses should also have knowledge on various blood parameters similar to the dialysis process. Such evaluation will increase the patient's quality of care by the nurse and positively influence patient comfort.

Correlation analysis made between the scores that hemodialysis patients received from the TAS-20 and sub-dimensions and the biochemistry results, and the number of daily medications used and the relationship between them were evaluated (Table 3). Lai et al. (2017) examined the biological indicators and alexithymic appearance in renal failure patients who were grouped based on treatment modalities, and demonstrated that phosphorus and hemoglobin levels directly influenced psychological condition and there was an inversely proportional relationship. In the same study, they evaluated potassium, calcium, phosphorus and hemoglobin from the biomarker data of the patients and their emotional levels, and found them to be statistically significant. ${ }^{29}$ Calia et al. (2015) evaluated the emotional status of patients and alexithymia in their study. They compared the physical parameters they examined with creatinine and blood urea nitrogen levels. There was a statistical significance between alexithymia appearance and physiological parameters. Meanwhile, according to a self-evaluation scale related to negative emotion control, they only found a negative relationship between creatinine and negative emotion control. ${ }^{30}$

There may be changes in the patient's metabolic activities, blood circulation, physiological variables and psychological condition in renal failure. The fluid change in the body leads to stress and fatigue in order to adapt to the sudden changes in the biomarkers, irrespective of the CRF treatment that is used. Emotional status changes. Therefore, it is important for the nurse to periodically evaluate the records of this group of patients, who are followed up in the clinic and at home, including their biomarkers, and incorporate this into the care plans. At the same time, reducing stress, increasing harmony, planning the treatment and diet regime and increasing comfort are important indicators in reflecting the quality of nursing care. 
In conclusion, while urea, creatinine, phosphorus, CRP values were found to be high, hemoglobin, sodium, albumin and calcium values were found to be low from the selected biomarkers in individuals receiving hemodialysis treatment. The stress levels of the patients were high and it was determined that more than half of the patients had alexithymia. It was determined that there was a relationship between the variables on accompanying chronic disease and HSS physical sub-dimensions. A relationship was determined between HSS and CRP, between HSS physical sub-dimensions and TAS-20, creatinine, sodium and the number of medications used daily, and between the HSS psychosocial sub-dimension and CRP. We conclude that there was a relationship between TAS-20 and creatinine, between TAS- 1 and HSS, hemoglobin, hematocrit, between TAS-2 and creatinine and between TAS-3 and creatinine and potassium in individuals who undergo hemodialysis. In line with our conclusions, we found evidence of the potential influence of physical health on mental health. A repeated study may be planned with multiple measurements in order to determine the fluctuations and what their influences on patients are. In our study, we evaluated the medication quantities and not the active ingredients or the generic names of the medications. The evidence we expected to arrive at while designing our research was determined as a result of the study data.

\section{Declarations}

The Ethics Committee required for this research was the Ethics Committee of the University Institute of Humanities and Social Sciences in Turkey (decision number 351 dated 02.08.2016). Afterward, the institution was granted permission from the Research Hospital ethics committee in Turkey where the research was conducted and the clinical chiefs were informed (decision number 1181 dated 28.09.2016). Consent was obtained in writing from the people who participated in the study which was based on voluntary participation.

The authors declare no conflict of interest.

\section{REFERENCES}

1 Ozdemir U, Tasc1 S. Psychosocial Problems And Care Of Chronic Diseases. Erciyes University Medical Science Journal. 2013;1:57-72. Available form: https://dergipark.org.tr/ tr/download/article-file/66941. Turkish with English abstract.

2 Sezer MT. Psychiatric Issues. Hemodialysis Physician Handbook, Istanbul: Turkish Nephrology Society Publication. 1997:147-52. Available from: http://www.nefroloji.org.tr/ folders/file/psikiyatrik_sorunlar.pdf. Turkish.

3 Akdemir N, Birol L. Internal Medicine and Nursing Care. Ankara: System Offset. 2011:578-606. Turkish.
4 Kara B. Adherence to treatment in hemodialysis patients: a multipleaspect approach. Gulhane Tip Derg. 2017;49:132-6. Available from: http://gulhanemedj.org/uploads/pdf/pdf_GMJ_364.pdf Turkish with English abstract.

5 Senturk A, Levent BA, Tamam L. The Psychopathology in Patients with Chronic Renal Failure Treated with Hemodialysis. Ondokuz Mayıs University Medical Journal. 2000;17:16372. Available from: https://dergipark.org.tr/download/articlefile/189259. Turkish with English abstract.

6 Sifneos PE. Alexithymia: past and present. Am J Psychiatry. 1996;153(suppl):137-42. DOI: 10.1176/ajp.153.7.137, PMID: 8659637

7 Sasioglu M, Gulol C, Tosun A. The Concept of Alexithymia. Psikiyatride Guncel Yaklasimlar - Current Approaches in Psychiatry. 2013;5:507-27. DOI: 10.5455/cap.20130531 Turkish with English abstract.

8 Kauhanen J, Kaplan GA, Julkunen J, Wilson TW, Salonen JT. Social factors in alexithymia. Compr Psychiatry. 1993;34:3305. DOI: 10.1016/0010-440X(93)90019-Z, PMID: 8306643

9 Quilty LC, Taylor GJ, McBride C, Bagby RM. Relationships among alexithymia, therapeutic alliance, and psychotherapy outcome in major depressive disorder. Psychiatry Res. 2017;254:75-9. DOI: 10.1016/j.psychres.2017.04.047, PMID: 28456025

10 Pistorio ML, Veroux M, Sinagra N, Basile G, De Pasquale C. Alexithymia in Kidney Transplantation Patients. Transplant Proc. 2017;49:642-5. DOI: 10.1016/j.transproceed.2017.02.031, PMID: 28457363

11 Okanli A, Karabulutlu EY, Asi Karakaş S, Şahin Altun Ö, Yildirim N. Alexithymia and perception of illness in patients with cancer. Eur J Cancer Care (Engl). 2018;27:e12839. DOI: 10.1111/ecc.12839, PMID: 29611248

12 Pop-Jordanova N, Polenakovic M. Alexithymia Construct in Dialysis Patients. BANTAO Journal. 2015;12:45-51. DOI: 10.2478/bj-2014-0010

13 Kojima M, Hayano J, Tokudome S, Suzuki S, Ibuki K, Tomizawa $\mathrm{H}$, et al. Independent associations of alexithymia and social support with depression in hemodialysis patients. J Psychosom Res. 2007;63:349-56. DOI: 10.1016/ j.jpsychores.2007.04.002, PMID: 17905041

14 Akyol AD, Karadakovan A. The Investigation of Influence Factors on Self-Care Agency and Ouality of Life on Hemodialysis Patients. Ege Journal of Medicine. 2002;41:97102. Available from: http://egetipdergisi.com.tr/tr/download/ article-file/349991. Turkish with English abstract.

15 Axelsson L, Alvariza A, Lindberg J, Öhlén J, Håkanson C, Reimertz H, et al. Unmet palliative care needs among patients with end-stage kidney disease: a national registry study about the last week of life. J Pain Symptom Manage. 2018;55:23644. DOI: 10.1016/j.jpainsymman.2017.09.015, PMID: 28941964

16 Kara B. Validity and Reliability Study of the Hemodialysis Stressor Scale. Journal of Health Education Research, Zonguldak Health College. 2006;2:64-71. (Control number: 3387540). Turkish with English abstract.

17 Gulec H, Kose S, Gulec M, Citak S, Evren C, Borckardt J, et al. Reliability and Factorial Validity of the Turkish Version 20-item Toronto Alexithymia Scale (TAS-20). Klinik Psikofarmakol Bülteni. 2009;19:214-20. Available from: http://pcp. psikofarmakoloji.org/pdf/TR/19_3_2.pdf

18 Salbas E. The Twenty-Item Toronto Alexithymia Scale (TAS-20). 2016 [cited 2017 May 20]. Available from: http:// www.ftronline.com/toronto-aleksitimi-olcegi/. Turkish. 
19 Sinatra M, Curci A, Palo V, Monacis L, Tanucci G. How Dialysis Patients Live: A Study on Their Depression and Associated Factors in Southern Italy. Psychology (Irvine). 2011;02:969-77. DOI: 10.4236/psych.2011.29146

20 Davison SN, Jhangri GS. The impact of chronic pain on depression, sleep, and the desire to withdraw from dialysis in hemodialysis patients. J Pain Symptom Manage. 2005;30:46573. DOI: 10.1016/j.jpainsymman.2005.05.013, PMID: 16310620

21 Demir B, Okanli A. The Determination of Relaxation Exercises Effect on Anger and Anger Control in Hemodialysis Patients. Journal of Anatolia Nursing and Health Sciences. 2013;16:227-33. Turkish with English abstract.

22 Griva K, Davenport A, Harrison M, Newman S. An evaluation of illness, treatment perceptions, and depression in hospital- vs. home-based dialysis modalities. J Psychosom Res. 2010;69:363-70. DOI: 10.1016/j.jpsychores.2010.04.008, PMID: 20846537

23 Spiegel BMR, Melmed G, Robbins S, Esrailian E. Biomarkers and health-related quality of life in end-stage renal disease: a systematic review. Clin J Am Soc Nephrol. 2008;3:1759-68. DOI: 10.2215/CJN.00820208, PMID: 18832106

24 Kalender B, Erdogan MS, Sengul E, Serdengecti K, Erek E, Yilmaz A. The Relationship Between Nutritional Status and Adequacy of Dialysis in Hemodialysis Patients. Cerrahpaşa J Med. 2002;33:223-30. Available from: http://www.ctf.edu. tr/dergi/online/2002v33/s4/024a4.pdf. Turkish with English abstract.
25 Shahrokhi Z, Rayyani M, Sabzevari S, Haghdoost AA. Stressors and Coping Strategies in Dialysis Patients. Iranian Journal of Critical Care Nursing. 2014;7:184-93. Available from: https://pdfs.semanticscholar.org/3 da0/ d2ed91f95570abbafe34ed642ad0ab969c79.pdf

26 Mok E, Tam B. Stressors and coping methods among chronic haemodialysis patients in Hong Kong. J Clin Nurs. 2001;10:503-11. DOI: 10.1046/j.1365-2702.2001.00500.x, PMID: 11822498

27 Ahmad MM, Al Nazly EK. Hemodialysis: stressors and coping strategies. Psychol Health Med. 2015;20:477-87. DOI: 10.1080/13548506.2014.952239, PMID: 25158058

28 Harwood L, Wilson B, Locking-Cusolito H, Sontrop J, Spittal J. Stressors and coping in individuals with chronic kidney disease. Nephrol Nurs J. 2009;36:265-76, 301. PMID: 19588694

29 Lai C, Aceto P, Luciani M, Fazzari E, Cesari V, Luciano $\mathrm{S}$, et al. Emotional management and biological markers of dietetic regimen in chronic kidney disease patients. Ren Fail. 2017;39:173-8. DOI: 10.1080/0886022X.2016.1256312, PMID: 27846784

30 Calia R, Lai C, Aceto P, Luciani M, Camardese G, Lai S, et al. Emotional self-efficacy and alexithymia may affect compliance, renal function and quality of life in kidney transplant recipients: results from a preliminary crosssectional study. Physiol Behav. 2015;142:152-4. DOI: 10.1016/ j.physbeh.2015.02.018, PMID: 25680476 